\title{
Peningkatan Keterampilan Proses Sains dan Penguasaan Konsep Gelombang Cahaya dengan Penerapan Model Inkuiri Berbantuan Simulasi PhET di Kelas XI MIPA E SMAN 2 Kota Bengkulu
}

\author{
Enna Marti Eka Putri, Irwan Koto, Desy Hanisa Putri \\ Prodi Pendidikan Fisika FKIP-UNIB \\ E-mail: putrienna4@gmail.com
}

\begin{abstract}
ABSTRAK
Penelitian tindakan kelas ini bertujuan untuk meningkatkan keterampilan proses sains dan penguasaan konsep gelombang cahaya dengan penerapan model Inkuiri berbantuan simulasi PhET. Subjek penelitian adalah siswa kelas XI MIPA E SMA Negeri 2 Kota Bengkulu. Instrumen penelitian yang digunakan adalah lembar observasi untuk mendeskripsikan aktivitas guru dan siswa, lembar tes untuk mendeskripsikan keterampilan proses sains dan penguasaan konsep gelombang cahaya. Hasil analisis data observasi aktivitas guru siklus I diperoleh skor rata-rata 16,5 (kriteria cukup), pada siklus II mengalami peningkatan menjadi 19,5 (kriteria baik), pada siklus III aktivitas guru kembali meningkat hingga skor rata-rata m encapai skor maksimal yaitu 21 (kriteria baik). Hasil analisis data observasi aktivitas siswa siklus I diperoleh skor rata-rata 17,5 (kriteria baik), pada siklus II mengalami peningkatan menjadi 20 (kriteria baik), pada siklus III aktivitas siswa kembali meningkat hingga skor rata-rata mencapai skor maksimal yaitu 21 (kriteria baik). Hasil penelitian menunjukkan bahwa skor rata-rata keterampilan proses sains pada siklus I sebesar 64,24 (kriteria cukup), pada siklus II sebesar 79,63 (kriteria baik), dan pada siklus III sebesar 92,96 (kriteria sangat baik). Penguasaan konsep gelombang cahaya pada siklus I sebesar 77,27 (kriteria baik), pada siklus II sebesar 87,04 (kriteria baik), dan pada siklus III 90,74 (kriteria sangat baik). Disimpulkan bahwa pembelajaran dengan penerapan model Inkuiri berbantuan simulasi PhET dapat meningkatkan keterampilan proses sains dan penguasaan konsep gelombang cahaya.
\end{abstract}

Kata kunci: Aktivitas Siswa, Keterampilan Proses Sains, Penguasaan Konsep gelombang cahaya, Model Inkiuiri, simulasi PhET.

\begin{abstract}
The aims of classroom action research was to improve the science process skills and mastery the concept of light waves with the implementation of Phet's simulated assisted inquiry model. The subject of study were students of class XI MIPA E SMA Negeri 2 Bengkulu city. The instrument used was the observation sheet to describes the activities of teacher and students, while the test sheet was used to describes the science process skills and mastery the concept of light waves. The results of teacher activity observation cycle I obtained an average score of 16,5 (enough criteria), in cycle II has increased to 19,5 (good criteria), in cycle III teacher activity again increase until score average reach maximum is 21 (good criteria). The results of students activity observation cycle I obtained an average score of 17,5 (good criteria), in cycle II has increased to 19,5 (good criteria), in cycle III students activity again increase until score average reach maximum was 21 (good criteria). The results showed that the average score of science process skills in cycle I was 64.24 (enough criteria), in the second cycle was 79.63 (good criteria), and in the third cycle was 92.96 (very good criteria) . Mastery the concept of light waves in the first cycle of 77.27 (good criteria), on the second cycle of 87.04 (good criteria), and in cycle III 90.74 (very good criteria). It was concluded that learning with the implementation of Phet's simulated assisted inquiry model can improve the science process skills and mastery the concept of light waves.
\end{abstract}

Keywords: Student Activity, Science Process Skills, Mastery the Concept of Light Waves, Inkiuiri Model, PhET simulation. 


\section{PENDAHULUAN}

Menurut UU Nomor 22 Tahun 2016 Tentang Standar Proses Pendidikan Dasar dan Menengah, Standar Kompetensi Lulusan pada proses pembelajaran mengacu kepada 3 aspek, yaitu: sikap, pengetahuan, dan keterampilan yang dielaborasi untuk setiap satuan pendidikan. Ketiga aspek tersebut diperoleh melalui lintasan proses yang berbeda. Kompetensi sikap diperoleh melalui aktivitas "menerima, menjalankan, menghargai, menghayati, dan mengamalkan. Kompetensi pengetahuan diperoleh melalui aktiviats "mengingat, memahami, menerapkan, menganalisis dan mengevaluasi. Sedangkan kompetensi keterampilan diperoleh melalui aktivitas "mengamati, menanya, mencoba, menalar, menyaji dan mencipta".

UU nomor 23 tahun 2016 tentang standar penilaian menyatakan bahwa Penilaian aspek sikap dapat dilaksanakan melalui observasi/ pengamatan dan teknik penilaian lain yang relevan. Penilaian aspek pengetahuan dilakukan melalui tes tertulis, tes lisan, dan penugasan sesuai dengan kompetensi yang dinilai. Penilaian keterampilan dilakukan melalui praktik, produk, proyek, portofolio, dan/atau teknik lain sesuai dengan kompetensi yang dinilai. Siswa dikatakan berhasil jika nilai pada ketiga aspek tersebut mencapai Kriteria Ketuntasan Minimal (KKM). KKM ditentukan oleh satuan pendidikan melalui rapat dewan pendidik dengan mempertimbangkan karakteristik peserta didik, karakteristik mata pelajaran, dan kondisi satuan pendidikan. Siswa yang tidak mencapai KKM harus mengikuti remedi. Hasil pencapaian siswa setelah mengikuti proses pembelajaran dilaporkan dalam bentuk angka dan/ atau deskripsi. Berdasarkan uraian diatas dapat disimpulkan bahwa selain hasil pembelajaran, kurikum 2013 menekankan pada pelaksanaan proses pembelajaran. Kurikulum 2013 menuntut siswa mengoptimalkan keterampilan proses sehingga model pembelajaran pada kurikulum 2013 didesain dan menggunakan tahapan-tahapan scientifik yang dapat melatih keterampilan proses siswa. Model pembelajaran yang menggunakan tahapan scientifik menurut standar proses kurikulum 2013 adalah model pembelajaran berbasis penyingkapan/ penelitian (discovery/inquiry learning) dan model pembelajaran berbasis pemecahan masalah (project based learning).

Berdasarkan pengamatan di kelas XI MIPA E SMA Negeri 2 Kota Bengkulu, beberapa permasalahan dalam proses pembelajran adalah: 1) Materi pembelajaran disampaikan dengan metode ceramah menggunakan bantun microsoft power point (PPT), kemudian siswa mencatat persamaan-persamaan Fisika yang ada pada slide, 2) Siswa tidak mampu menginterpretasikan besaran-besaran pada soal cerita kedalam bentuk simbol-simbol Fisika, karena siswa hanya menghapalkan persamaan-persamaan Fisika, 3) Keterampilan proses sains (KPS) siswa masih rendah. Terlihat pada saat pelaksanaan percobaan di Laboratorium, dimana indikator KPS seperti: mengamati, mengajukan permasalahan, merumuskan hipotesis, mengklasifikasi dan menginterpretasi data, serta mengkomunikasikan data percobaan masih kurang tereksplor dengan baik. Hal ini karena frekuensi pelaksanaan percobaan yang minim, dalam satu semester melaksanakan 2 atau 3 kali percobaan. Padahal pelaksanaan percobaan yang menggunakan tahapan scientifik dapat melatih keterampilan proses sains siswa, 4) Waktu untuk melaksanakan percobaan kurang efektif. Alokasi waktu untuk percobaan hanya 2 jam pembelajarn (90 menit).

Berdasarkan hasil diskusi dengan guru, maka perlu dilakukan perbaikan proses pembelajaran. Salah satu cara yaitu melalui penerapan model dan media pembelajaraan yang tepat. Model pembelajaran yang dapat meningkatkan (KPS) dan penguasaan konsep siswa adalah model pembelajaran Inkuiri.Inkuiri merupakan siklus membangun pengetahuan atau konsep[1]. Siklus Inkuiri dimulai dari: 1) observasi atau pengamatan, 2) mengajukan pertanyaan, 3) mengajukan dugaan atau kemungkinan jawaban, 4) mengumpulkan data, 5) merumuskan Kesimpulan[2]. Model pembelajaran inkuiri dapat meningkatkan KPS, karena indikator KPS: mengamati, merumuskan permasalahan, menyusun hipotesis, mengklasifikasikan dan menginterpretasi data, serta mengkomunikasikan, sesuai dengan sintak Inkuiri, yaitu: mengamati, mengajukan permasalahan, merumuskan hipotesis, pengumpulan data, dan menarik kesimpulan. Melalui penerapan model pembelajaran inkuiri 
dan KPS penguasaan konsep akan meningkat karena konsep pembelajaran merupakan penemuan siswa selama proses pembelajaran.

Permasalahan tentang kurang efektifnya pelaksanaan percobaan dapat diatasi dengan penggunaan media pembelajaran yang tepat. Salah satu alternatif yang dapat digunakan adalah simulasi PhET (Physic Education Technology)[3], menyatakan bahwa Simulasi PhET adalah suatu simulasi interaktif yang menggunakan bahasa pemograman java dan flash, yang dikembangkan oleh tim dari Universitas Colorado Amerika Serikat. Simulasi Phet didapatkan secara gratis dengan mengunduh di website resminya https://phet.colorado.edu. Simulasi PhET memliki beberapa manfaat.Manfaat simulasi PhET adalah: 1) membutuhkan keterlibatan dan interaksi dengan siswa, 2) memberi feedback yang dinamis, 3) mendidik siswa agar memiliki pola berfikir konstruktivisme, 4) menciptakan suasana belajar yang menarik, karena siswa dapat belajar sambil bermain melalui simulasi, 5) mampu memvisualisasikan konsep-konsep fisika[4]

Menurut hasil penelitian sebelumnya, penerapan model pembelajaran inkuiri dengan memanfaatkan multimedia interaktif dapat meningkatkan penguasaan konsep dan keterampilan proses siswa. Peningkatan penguasaan konsep terjadi pada seluruh aspek yang diteliti, yakni: mengingat (C1), memahami (C2), dan menerapkan (C3). Begitu pula peningkatan keterampilan proses siswa yang meningkat pada kelima aspek yang diteliti, yakni: aspek interpretasi, klasifikasi, hipotesis, merencanakan percobaan dan menerapkan konsep[5].

Berdasarkan uraian diatas, perlu dilakukan penelitian yang berjudul Peningkatan Keterampilan Proses Sains dan Penguasaan Konsep Gelombang Cahaya dengan Penerapan Model Inkuiri Berbantuan Simulasi PhET dikelas XI MIPA E SMAN 2 Kota Bengkulu. Rumusan masalah dalam penelitian ini, yaitu: 1) apakah model pembelajaran inkuiri berbantuan simulasi PhET dapat meningkatkan aktivitas siswa pada konsep gelombang cahaya dikelas XI MIPA E SMAN 2 Kota Bengkulu?; 2) Apakah model pembelajaran inkuiri berbantuan simulasi PhET dapat meningkatkan keterampilan proses sains siswa pada konsep gelombang cahaya dikelas XI MIPA E SMAN 2 Kota Bengkulu?; 3) Apakah model pembelajaran inkuiri dapat meningkatkan penguasaan konsep gelombang cahaya siswa kelas XI MIPA E SMAN 2 Kota Bengkulu?

\section{METODE PENELITIAN}

Penelitian ini merupakan penelitian tindakan kelas (Classroom Action Research). Pelaksanaanya dilakukan tiga siklus dan tiap siklus terdiri dari empat tahap yang meliputi perencanaan, pelaksanaan, pengamatan dan refleksi[6]. Subjek penelitian ini adalah 36 siswa kelas XI MIPA E SMA Negeri 2 Kota Bengkulu tahun ajaran 2017/2018 yang terdiri dari 11 orang laki-laki dan 25 orang perempuan.

Instrumen peneltian terdiri dari lembar observasi aktivitas guru dan siswa, lembar tes dalam bentuk tes uraian serta lembar kerja peserta didik (LKPD). Sebelum perangkat digunakan dalam penelitian, perangkat tes diuji validitas terlebih dahulu oleh ahli yang terdiri dari satu orang dosen FKIP Fisika Universitas Bengkulu dan dua orang guru mata pelajaran Fisika SMA Negeri 2 Kota Bengkulu. Lembar observasi guru dan siswa digunakan untuk memperoleh informasi bagaimana guru dan siswa melaksanakan kegiatan belajar mengajar dengan penerapan model Inkuiri berbantuan simuasi PhET. Data lembar observasi digunakan pada tahap refleksi untuk merencanakan perbaikan pembelajaran pada siklus berikutnya. Sedangkan data hasil tes digunakan untuk mendeskripsikan keterampilan proses sains dan penguasaan konsep gelombnag cahaya.

Data penelitian dianalaisis secara kualitatif dan dan kuantitatif. Data aktivitas guru dan siswa pada penerapan model Inkuiri berbantuan simulasi PhET dianalisis secara kualitatif, sedangkan data keterampilan proses sains dan penguasaan konsep gelombang cahaya dianalisis secara kuantitatif dengan menentukan nilai rata-rata, standar deviasi, persentase ketuntasan belajar dan daya serap klasikal. 
Lembar bservasi menggunakan skor 3 (baik), 2 (cukup), dan 1 (kurang). Deskripsi hasil observasi aktivitas guru dan siswa diolah setelah rata-rata skor diketahui, kemudian diketahui kriteria skor observasi. Jumlah aspek pengamatan pada lembar observasi adalah 7 aspek yang disesuaikan dengan langkah-langkah Inkuiri. Skor tertinggi tiap aspek observasi adalah 3, sedangkan skor terendah adalah 1. Maka total skor tertinggi adalah 21 dan terendah 7, dengan kriteria baik (17-21), cukup (12-16) dan kurang (7-11).

Lembar kerja peserta didik digunakan untuk membimbing siswa merencanakan kegiatan yang akan dilaksanakan dengan menggunakan model pembelajaran Inkuiri berbantuan simulasi PhET. Selain itu, lembar kerja ini berfungsi untuk membimbing siswa dalam menemukan konsep pembelajaran melalui analisis data pada lembar kerja.

Adapun kriteria keberhasilan tindakan pada penelitian ini adalah: a) aktivitas siswa meningkat tiap siklus; b) ketuntasan keterampilan proses sains tercapai jika jika $\geq 75 \%$ siswa mendapat nilai $\geq 75$. Selain itu, indikator keberhasilan keterampilan proses sains (KPS) siswa tercapai jika KPS meningkat pada tiap siklus secara klasikal; c) keberhasilan pada aspek pengetahuan tercapai jika $\geq 75 \%$ siswa mendapat nilai $\geq 75$. penguasaan konsep siswa meningkat apabila siklus kedua lebih tinggi dari siklus pertama dan siklus ketiga lebih tinggi dari siklus kedua; d) daya serap meningkat apabila siklus kedua lebih tinggi dari siklus pertama dan siklus ketiga lebih tinggi dari siklus kedua

\section{HASIL DAN PEMBAHASAN}

Kegiatan belajar mengajar dengan menggunakan model pembelajaran Inkuiri berbantuan simulasi PhET pada konsep Gelombang Cahaya di kelas XI MIPA E SMA Negeri 2 Kota Bengkulu yang dilakukan sebanyak tiga siklus telah berhasil dilaksanakan. Pembelajaran pada siklus III lebih baik dari pembelajaran pada siklus II dan pembelajaran siklus II lebih baik dari pembelajaran siklus I. Perubahan pembelajaran terjadi karena adanya perbaikan pada setiap siklus. Adapun tujuan perbaikan ini untuk melihat kelemahan dan kelebihan yang ditemukan selama pembelajaran dengan cara merefleksi setiap akhir siklus untuk memperbaiki proses pembelajaran dan meningkatkan hasil belajar.

Rata-rata aktivitas guru meningkat dari kategori cukup pada siklus I (16) menjadi kategori baik pada siklus II (20) dan siklus III (21). Rata-rata aktivitas siswa mengalami peningkatan dari siklus I (17) ke siklus II (20) dan siklus III (21). Aktivitas guru dan siswa pada siklus I masih kurang maksimal yang ditunjukkan oleh perolehan KPS siswa yang rendah pada beberapa indikator mengamati, merumuskan permasalahan, menglasifi data penyelidikan dan mengkomunikasikan. Indikator merumuskan hipotesis dan menginterpretasidata sudah dikategorikan baik. Persentase ketuntasan KPS pada indikator mengamati, merumuskan permasalahan, dan mengklasifikasi berturut-turut adah $24 \%, 24 \%$, dan $18 \%$ dan $67 \%$. Persentase ketuntasan KPS pada indikator merumuskan hipotesisdan menginterpretasi data telah mencapai $80 \%$ dan $95 \%$.Hasil refleksi menunjukkan 1) aktivitas mengamati hanya 13 orang siswa yang mengamati karena stimulus yang diberikan guru berupa video tidakjelas; 2) persentase ketuntasan KPS pada indikator merumuskan masalah hanya 36\%, hal ini karena siswa belum terbiasa menyelesaikan soal KPS; 3) guru membimbing 3 kelompok pada aktivitas megklasifikasi dan menginterpretasi, seharusnya guru membimbing semua kelompok hingga setiap kelompok faham; 4) hanya 1 kelompok yang memperoleh bimbingan saat membuat kesimpulan karena kekurangan waktu diakhir pembelajaran; 5) 3 orang siswa tidak mengikuti pembelajaran.

Pada siklus II aktivitas guru dan siswa berada pada kategori baik. Aktivitas yang belum terlaksana secaramaksimal adalah aktivitas mengklasifikasi dan interpretasi data. Hasil refleksi siklus II menunjukkan bahwa pada aktivias ini aktivias guru dan siswa tidak mengalami peningkatan, meskipun telah direncanakan perbaikan pada siklus I. Namun, perbaikan yang tersebut tidak terealisasikan dilapangan. Guru mempersingkat waktu pada aktivitas mengklasifikasi dan interpretasi untuk menyediakan waktu pada aktivitas membuat 
kesimpulan. Secara keseluruhan aktivitas guru dan siswa pada siklus III berada pada kategori baik. Aktivitas siswa pada tiap siklus ditunjukkan Gambar 1.

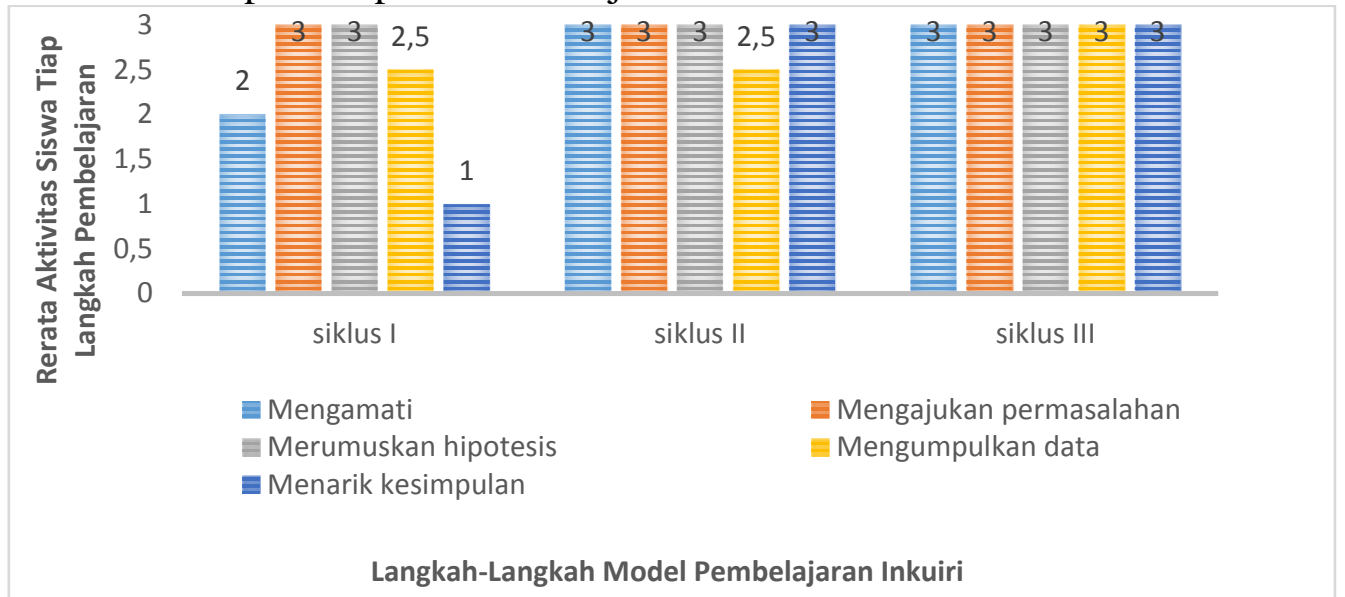

Gambar 1. Data Aktivitas Siswa pada Tiap siklus Pembelajaran

Berdasarkan gambar 1 terlihat bahwa penerapan model Inkuiri berbantuan simulasi PhET dapat meningkatkan aktivitas siswa. Hasil observasi ini sesuai dengan penelitian yang telah dilakukan oleh Septiawan (2013)[5], yang menyatakan bawha penerapan meodel pembelajaran Inkuiri dapat meningkatkan aktivitas siswa

Data KPS dan penguasaan konsep diperoleh dari lembar jawaban siswa yang diberikan pada setiap akhir siklus. Lembar jawaban tersebut digunakan untuk mengukur KPS dan penguasaan konsep gelombang cahaya. Penskorannya menggunakan rubrik penilaian KPS dan penguasaan konsep. Persentase keberhasilan KPS pada setiap indikator yang diteliti di setiap siklus pembelajaran ditunkkan oleh Tabel 1.

Tabel 3.1 Persentase Ketuntasan Indikator KPS Pada Setiap Siklus

\begin{tabular}{|c|c|c|c|c|c|c|}
\hline \multirow{2}{*}{ Siklus } & \multicolumn{5}{|c|}{ Persentase Ketuntasan KPS Pada Setiap Indikator } \\
\cline { 2 - 7 } & $\begin{array}{c}\text { Menga- } \\
\text { mati (\%) }\end{array}$ & $\begin{array}{c}\text { Merumusk- } \\
\text { an masalah } \\
(\%)\end{array}$ & $\begin{array}{c}\text { Merumusk- } \\
\text { an hipotesis } \\
(\%)\end{array}$ & $\begin{array}{c}\text { Mengkla- } \\
\text { sifikasi } \\
(\%)\end{array}$ & $\begin{array}{c}\text { Menginter } \\
\text {-pretasi } \\
(\%)\end{array}$ & $\begin{array}{c}\text { Mengkomu } \\
- \text { nikasikan } \\
(\%)\end{array}$ \\
\hline I & 24 & 24 & 76 & 18 & 97 & 67 \\
\hline II & 93 & 93 & 90 & 100 & 0 & 85 \\
\hline III & 96 & 93 & 93 & 96 & 85 & 96 \\
\hline
\end{tabular}

Tabel 3.1 menunjukkan bahwa tidak semua indikator KPS yang diteliti mengalami peningkatan pada setiap siklus. Indikator yang mengalami peningkatan disetiap siklus hanya pada mengamati dan mengkomunikasikan. Pada Indikator menginterpretasi persentase ketuntasan mengalami penurunan yang signifikan dari siklus I (97\%) ke siklus II (0\%) dan meningkat pada siklus III (85\%). Hal ini karena pada siklus II guru terburu-buru saat membimbing menginterpretasikan data. Selain itu materi siklus II lebih sulit dari siklus I dan III. Rendahnya persentase keberhasilan menginterpretasi juga diskarenakan siswa tidak menguasai persamaan yang digunakan pada soal tes.

Berdasarkan analisis data KPS, hasil penelitian menunjukkan bahwa KPS meningkat pada setiap siklus. Data KPS setiap siklus ditunjukkan Grafik 2.

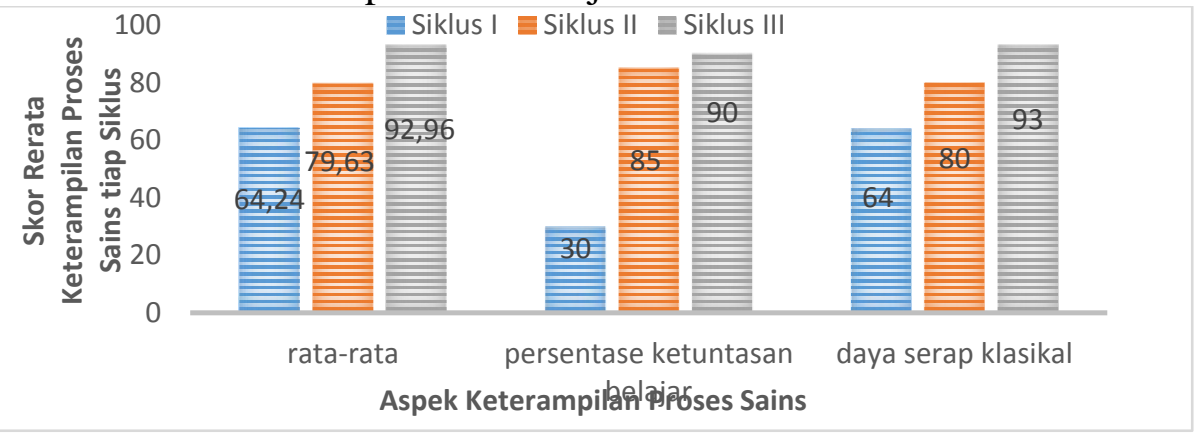

Gambar 2. Data keterampilan Proses Sains pada tiap Siklus 
Hasil penelitian menunjukkan penerapan model pembelajaran Inkuiri berbantuan simulasi dapat meningkatkan keterampilan proses sains pada konsep gelombang cahaya. Skor keterampilan proses sains pad siklus I belum tercapai karenasiswa yang memperoleh nilai $\geq 75$ $<75 \%$ yitu $\leq 30 \%$. Persentase ketuntasan meningkat pada siklus II dan siklus III, dimana $\geq 75 \%$ dari jumlah seluruh siswa memperoleh nilai $\geq 75$. Selain itu, daya serap klasikal meningkat tiap siklus. Berdasarkan grafik 2 terlihat bahwa pada siklus I rata-rata skor nilai siswa yaitu 64,24 dengan standar deviasi sebesar 10,00. Persentase ketuntasan belajar sebesar $30 \%$ dan daya serap klasikal 64\%. Pada siklus II pada grafik 4.5 terlihat bahwa rata-rata skor yaitu 79,63 dengan standar deviasi 16,60. Persentase ketuntasan belajar pada siklus II sebesar $85 \%$ dan daya serap klasikal $80 \%$. Sedangkan pada siklus III diperoleh skor rata-rata sebesar 92,96 dengan satandar deviasi sebesar 9,45. Persentase ketuntasan belajar pada siklus III sebesar $90 \%$ dan daya serap klasikal 93\%. Hasil penelitian menunjukkan bahwa penerapan model pembeljaran Inkuiri dapat meningkatkan keterampilan proses sains. Hal ini sesuai dengan hasil penelitian terdahulu yang menyatakan bahwa Penerepan model pembelajaran Inkuiri dapat meningkatkan keterampilan proses sains siswa[7].

Penguasaan konsep pada penelitian ini adalah pemahaman siswa kognitif ranah pengetauan/ knowledge (C1), pemahaan/ comprehension (C2), dan penerapan/ application (C3). Pemahaman setingkat lebih tinggi dari pengetahuan sehingga untuk memahami perlu terlebih dahulu mengetahui atau mengenal ${ }^{[8]}$. Aspek penerapan (C3) merupakan aspek yang lebih tinggi dari pemahaman (C2), pada aspek penerapan konsep yang harus dikuasai siswa harus lebih kompleks[9]. Penguasaan konsep pada penelitian ini diukur melalui tes kognitif yang terdiri dari 3 soal berbentuk soal uraian. Secara klasikal pemahaman Konsep siswa tiap siklus ditunjukkan oleh Gambar 3.

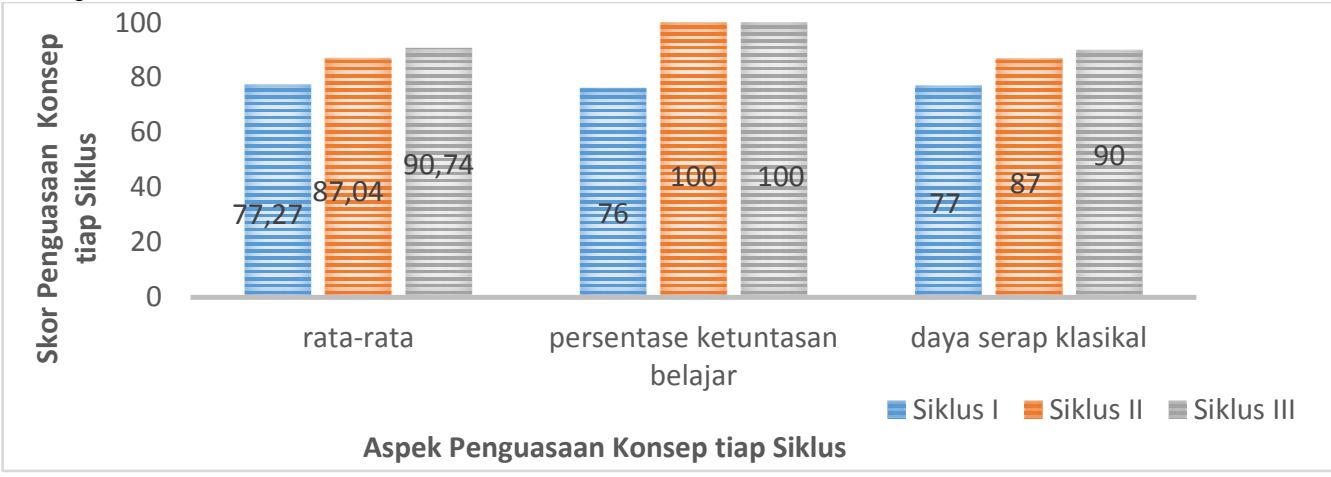

Gambar 3. Penguasaan Konsep Gelombang Cahaya tiap Siklus

Hasil penelitian menunjukkan penerapan model pembelajaran Inkuiri berbantuan simulasi dapat meningkatkan penguasaan konsep gelombang cahaya pada tiap siklus. Hasil belajar pada siklus I, siklus II, dan siklus III telah mencapai persentase ketuntasan belajar karena lebih dari $60 \%$ dari jumlah seluruh siswa memperoleh nilai $\geq 75$. Selain itu, daya serap klasikal meningkat tiap siklus.

Hasil penelitian menunjukkan bahwa penerapan model pembeljaran Inkuiri berbantuan simulasi PhET dapat meningkatkan penguasaan konsep gelombang cahaya. Hal ini sesuai dengan pendapat Septiawan (2012 $)^{[5]}$, yang menyatakan bahwa penerepan model pembelajaran Inkuiri dengan memanfaatkan media interaktif dapat meningkatkan penguasaan konsep dan keterampilan proses siswa. Penerapann model pembelajaran Inkuiri berbantuan simulasi PhET membuat siswa lebih aktif selama proses pembelajaran. Selain itu, penggunaan simulasi PhET sangat efektif untuk meningkatkan diminati siswa karena designnya menarik, dapat diguanakan kapanpun dan dimanapun siswa menginginkannya hanya dengan menggunakan gadget dan menginstal software simulasi tersebut.

\section{SIMPULAN DAN SARAN}

Disimpulkan bahwa: 1) Model Inkuiri berbantuan simulasi PhET dapat meningkatan aktivitas siswa. Meskipun masih terdapat aktivitas yang tidak mengalami peningkatan pada 
setiap siklus, namun rata-rata aktivitas siswa telah mengalami peningkatan. Pada siklus I aktivitas mengamati dan mengumpulkan data berada pada kategori cukup, aktivitas membuat kesimpulan berada pada kategori kurang. Hasil refleksi siklus II menunjukkan peningkatan aktivias mengamati dan membuat kesimpulan, namun aktivitas mengumpulkan data tidak mengalami peningkatan. Pada siklus III aktivitas siswa mengalami peningkatan pada setiap aspek; 2) Rata-rata KPS siswa pada siklus I berada pada kategori kurang. Kemudian pada siklus II mengalami peningkatan. KPS pada siklus II berada pada kategori cukup. Pada siklus III KPS kembali meningkat. KPS pada siklus III berada pada sangat baik. Hasil penelitian menunjukkan KPS meningkat pada setiap siklus. Jadi, penerapan model pembelajaran Inkuiri berbantuan simulasi PhET dapat meningkatkan keterampilan proses sains pada konsep gelombang cahaya di kelas XI MIPA E SMA Negeri 2 kota Bengkulu; 3) Penerapan model pembelajaran Inkuiri berbantuan simulasi PhET dapat meningkatkan penguasaan konsep gelombang cahaya siswa di kelas XI MIPA E SMA Negeri 2 kota Bengkulu. Rata-rata nilai penguasaan konsep Gelombang Cahaya telah meningkat pada setiap siklus. Keberhasilan aspek pengetahuan telah memenuhi kriteria ketuntasan minimum. Selain itu,daya serap siswa pada siklus II lebih tinggi dari siklus I dan daya serap siklus III lebih tinggi dari siklus II.

Untuk penelitan selanjutnya diharapkan: 1) Siswa dan guru harus terampil menggunakan gadget dan simulasi interaktif yang digunakan; 2) Penggunaan simulasi PhET merupakan alternatif yang sangat tepat untuk menumbuhkan semangat belajar siswa, terutama bagi siswa yang senang menggunakan gadget; 3) Pada saat pembelajaran berlangsung, hendaknya guru memperhatikan apakah siswa telah memahami apa yang disampaikan sesuai dengan tujuan pembelajaran sebelum melanjutkan pembelajaran kelangkah berikutnya.

\section{DAFTAR PUSTAKA}

[1] Wisudawati, A. W., \& Sulistyowati, E. 2014. Metodologi Pembelajaran IPA. Jakarta: PT Bumi Aksara

[2] Damayanti, I. 2014. Penerapan Model Pembelajaran Inkuiri Untuk Meningkatkan Hasil Belajar Mata Pelajaran IPA Sekolah Dasar. Jurnal PGSD FIP Universitas Negeri Surabaya, Volume 02

[3] Fithriani, S. L., Halim, A., \& Khaldun, I. 2015. Penggunaan Simulasi Phet dengan Pendekatan Inkuiri Terbimbing untuk Meningkatkan Keterampilan Berfikir Kritis Siswa pada Pokok Bahasan Kalor di SMA Negeri 12 Banda Aceh. Jurnal Unsyiah

[4] Perdana, A., Siswoyo, \& Sunaryo. (2017). penegembangan Lembar Kerja Siswa Berbasis Discovery Learning Berbantuan PHET Interactive Simulations pada Materi Hukum Newton. Jurnal wahana Pendidikan Fisika, Volume 2

[5] Septiawan, Ahmad F. 2012. Penerapan Model Pembelajaran Inkuiri dengan Memanfaatkan Multimedia Interaktif untuk Meningkatkan Penguasaan Konsep dan Keterampilan Proses Siswa. S2 Thesis Universistas Pendidikan Indonesia

[6] Arikunto, Suharsimi. 2010. Prosedur Penelitian. Jakarta: Rineka Cipta

[7] Rahmasiswi, Amining. 2015. Peningkatan Keterampilan Proses Sains Siswa dalam Pembelajaran Biologi Melalui penerapn Model pembelajaran Inkuiri dikelas XI MIA 9 (ICT) SMA Negeri 1 Karanganyar Tahun Pelajaran 2014/2015. e-jurnal FKIP UNS

[8] Sudjana. 2006. Metode Statistik. Jakarta: Rineka Cipta

[9] Kaniawati, ida. 2017. Pengaruh Simulasi Komputer Terhadap PeningkatanPenguasaan Konsep Impuls-Momentum Siswa SMA. Jurnal Pembelajaran Sains, Volume 1 